\title{
Benthic foraminifera as indicators of river discharge in the Western South Atlantic continental shelf margin
}

\author{
Patrícia P.B. Eichler ${ }^{1} 2^{\star}$, André Rosch Rodrigues ${ }^{3}$
}

1. Programa de Pós-Graduação em Geofísica e Geodinâmica (PPGG), Universidade Federal do Rio Grande do Norte (GGEMMA, CCET, UFRN). Campus Universitário, Lagoa Nova, 59072-970, Natal, RN, Brazil. Phone: 55 (84) 32153807 ext. 237. patriciaeichler@gmail.com, *corresponding author, gomesmp@geologia.ufrn.br, helenice@geologia.ufrn.br

2. Universidade do Sul de Santa Catarina (UNISUL). Av. Pedra Branca, 25, Cidade Universitária, Palhoça, SC, 88137-270, Brazil.

3. Programa de Pós-Graduação em Oceanografia, Universidade Federal de Santa Catarina (UFSC) Campus Universitário, Florianópolis, SC, 88040-900, Brazil. andre.rosch.rodrigues@gmail.com

Abstract

The present work focuses on fresh water signatures at the sediment-water interface $(1 \mathrm{~cm})$ using foraminiferal species in both austral winter and summer in eleven longitudinal transects on the Western South Atlantic continental margin between $27^{\circ}$ and $37^{\circ} \mathrm{S}$, at water depths of 11.7 to $250 \mathrm{~m}$. Here we show that depth, salinity, temperature, oxygen, grain size (mud and sand percentage), suspended matter, organic matter, $\mathrm{SiO}_{4}$,

$21 \mathrm{NO}_{2}$, and $\mathrm{NO}_{3}$ in this order of importance are responsible for the distribution of 22 foraminiferal species and thecamoebians. The presence of these microfossils indicate 23 freshwater influx in four sectors over the continental shelf: Itajaí-Açu River, Laguna estuarine system, Patos Lagoon and RdIP (Rio de la Plata) will be explored further in detail. Our findings on freshwater signature on the continental shelf sediments through benthic species indicator are comparable to other continental systems worldwide, and a paleo record study would be useful for three South American countries (Brazil, Argentina and Uruguay). A freshwater signature in the continental shelf indicates deposition sites probably linked to anthropogenic impact since most of the pollutants and contaminants are dumped into water bodies that eventually reach and accumulate in the ocean.

31 Therefore, the freshwater-related species on the continental shelf reflects exactly where 32 the depositional sediment sites are, and where anthropogenic impacts accumulate. 
33 Foraminiferal microhabitat occupation within these zones is discussed in detail. And we

34 conclude that together with the fauna, the abiotic parameters play an important role in 35 determining the occurrence and degree of marine eutrophication induced by the input of 36 polluted river waters, also showing possible anoxic environments on the shelf.

37 Keywords: Western South Atlantic continental margin; benthic Foraminifera; fresh 38 water; nutrients, eutrophication, anoxic.

\section{Introduction}

The Western South Atlantic continental margin is influenced by freshwater input from the drainage basin of Rio de la Plata (RdIP). It is the second largest basin in South America and receives more than $75 \%$ of its discharge from Paraná River, Uruguay River (Depetris and Paolini, 1991), and other tributaries, in the southern coast of Brazil, such as the Patos-Mirim Lagoon, Estuarine complex of Laguna, and Itajaí Açu River.

The discharge from RdIP is of about $21,000 \mathrm{~m}^{3} \mathrm{~s}^{-1}$, naturally slightly higher during late summer, and maximum discharge occurs where the historical maxima of river discharge during the year following the onset of during El Niño periods which triples relative to typical Mean River discharge (Berbery and Barros, 2002). In addition, the plume penetration of the RdIP along shore faces opposing summer northeasterly winds 51 (Piola et al., 2005).

This hydrographic system extends from the subequatorial zone through the tropics, funneling its numerous tributaries into RdIP, which are discharged into the South

54 Atlantic Ocean, and spread along the coasts of Argentina, Uruguay and Brazil (Figure 1). This coastal zone water mass (CW) outflow influences the near-shore ecosystem

56 (Ciotti et al., 1995; Muelbert and Sinque, 1996; Sunyé and Servain, 1998) exporting

57 carbon from the continent into the oceans (Degens et al., 1991).

The continental margin, between $27^{\circ}$ and $37^{\circ} \mathrm{S}$, is dominated by four main water masses: cold-fresh Sub Antarctic Shelf Water (SASW), warm-salty Subtropical Shelf 
60 Water (STSW), cold upwelled South Atlantic Central Water (SACW), and the coastal

61 Plata Plume Water (PPW) from RdIP.

62 Previous articles on the Western South Atlantic continental margin demonstrate

63 the spatial distribution of benthic foraminifera is related to water mass dynamics (Burone

64 et al., 2013, Eichler et al., 2014; 2016). Specifically Eichler et al. (2014) showed that

65 Bulimina marginata is tolerant species to transitional zones and influenced by location of

66 Subtropical Shelf Front (STSF), a complex regional extension of the Brazil/Malvinas

67 Confluence Zone over the shelf defined by a thermohaline subsurface front between

68 STSW and SASW described by Piola et al. (2008). Later on, Eichler et al. (2016) showed

69 that spatial abundance of infaunal benthic foraminiferal species Buccella peruviana,

70 Globocassidulina subglobosa, and Uvigerina peregrina are responding to the interaction

71 of SASW, STSW and upwelling of SACW respectively.

72 Scott and Medioli (1980) showed that Arenoparella mexicana and Trochammina

73 inflata occurred in all marshes from high to low salinity, and Murray (1991) suggested

74 that A. mexicana, Ammoastuta salsa, Haplophragmoides wilberti and Trochammina sp.

75 are species typical of coastal salt marshes and are more abundant where freshwater

76 input is higher. Worldwide freshwater input (Murray, 2006, Debenay et al., 2006) is

77 related to faunal response among other environmental variables. Thecamoebians are

78 testate protists that occur in a variety of freshwater habitats and brackish environments

79 and have been successfully used as proxies for a variety of environmental and climatic

80 parameters in limnological and paleolimnological studies (Farooqui, et al., 2012). They

81 are truly fresh water microorganisms.

82 Present studies consider details on the signature of freshwater on selected 83 benthic microorganisms found in the sediment-water interface $(1 \mathrm{cmbsf})$. We intend to 84 investigate the influence of RdIP plume and other local river discharge including the 85 Itajaí-Açu system, the Laguna estuarine system, and the Patos lagoon over the 86 continental shelf. Specifically, we seek to examine whether flocculation influences 87 foraminiferal dynamics, and how microhabitats of these organisms vary. This question 
88

89

90

91

92

93

94

has implications for the influence of river discharge on water mass dynamics in this area, and in turn, on the benthic species dynamics of marine bottom sediment on the continental shelf. Our findings are comparable to estuaries worldwide and can indicate potential polluted zones on the coastal marine sediments.

\section{Material and Methods}

2.1 Sample Collection

95

Sampling was done on a shelf region bound by the offshore Brazil/Malvinas current system and inshore by the freshwater source of RdIP up to water depths of 250 m. During two oceanographic cruises, 120 surface sediment samples were collected in both austral winter (August, $20^{\text {th }}$ to September, $2^{\text {nd }} 2003,64$ samples) and summer (February, $1^{\text {st }}$ to $19^{\text {th }} 2004,56$ samples).

A Van Veen Grab sampler was used in 11 transects in water depths of 10 and $250 \mathrm{~m}$. These transects from south to north were named as follows: Mar del Plata, Punta Medanos, Plata River, Punta del Este, Punta del Diablo, Albardão, Rio Grande, Solidão, Torres, Santa Marta Cape, and Itajaí in water depths ranging from 10 to 250m (Figure 2).

\subsection{Field and laboratory procedures for Foraminiferal study}

After collection, the uppermost layer of the sediment sample (about $1 \mathrm{~cm}$ ) was scraped off and kept in ethanol. A solution of Rose Bengal in ethanol was used for staining live specimens for $48 \mathrm{hs}$. A fixed volume of $10 \mathrm{~cm}^{3}$ of sediment was washed through a $63 \mu \mathrm{m}$ sieve and oven dried at $60^{\circ} \mathrm{C}$. The samples were then floated using trichloroethylene $\left(\mathrm{C}_{2} \mathrm{HCl}_{3}\right)$ to separate shells from sediment. Processed samples were split from $63 \mu \mathrm{m}$ size fraction with a microsplitter to obtain at least 100 specimens of benthic foraminifera per sample (Fatela and Taborda, 2002). All foraminifera were picked from a split and included in the quantitative analysis of the assemblage counts. Unsplit samples from some stations did not contain 100 tests, but they were taken into account. Planktonic foraminifera were counted, however it was not considered in the analysis. 
116 Data on total (dead plus living) benthic foraminifera are used here. The analysis of total

117 assemblage of benthic foraminifera was chosen because dead and living foraminifera

118 provide insight into different aspects of the environment. While dead benthic foraminiferal

119 assemblages give a time-averaged record over a period of one to several years (Murray,

120 2001), the living foraminifera thriving at their optimum environmental conditions

121 reproduce more often (Martins et al. 2015) giving us a snapshot of this current moment.

122 By combining total benthic foraminiferal assemblages with environmental variables, we

123 were able to track and average signature of the present bottom environmental and 124 oceanographic conditions for the last year.

125 Identification and counting of specimens were done under a Stemi V6 Zeiss 126 stereomicroscope, and taxonomy followed Ellis and Messina (1940). Scanning electron 127 micrographs were taken to help with some problematic identifications. Absolute and 128 relative abundances were computed for all specimens. All species have morphological 129 characters easily observed and future studies will not face taxonomical ambiguity.

\subsection{Water samples}

Nutrient analysis data on water samples were taken from Braga et al. (2008) came from bottom or near-bottom water (less than $1 \mathrm{~m}$ ) from most of the stations.

134 Temperature $\left({ }^{\circ} \mathrm{C}\right)$ and salinity (PSU) were recorded at every station using the model 911

135 CTD from SeaBird Electronics.

136 Samples for dissolved oxygen and nutrients were collected in bottles mounted on

137 a rosette. Data analysis from the entire water column is described in Braga et al. (2008),

138 however in our work, we have exclusively used data for bottom water. Dissolved oxygen

$139\left(\mathrm{~mL} \cdot \mathrm{L}^{-1}\right)$ was first extracted and measured by the Winkler procedure using an automated 140 titration method (Grasshoff et al., 1983).

141 The dissolved nutrients analyzed were silicate, nitrite, and nitrate $(\mu \mathrm{M})$. The 142 dissolved nutrients were filtered through Whatman GF/F membranes. The samples were 143 frozen $\left(-20^{\circ} \mathrm{C}\right)$ and the analyses of nitrate and nitrite were performed using an automated 
144 system (AutoAnalyzer II - Bran-Luebbe), following the procedure in Grasshoff et al.

145 (1983). The silicate analyses were done by a spectrophotometric method. The 146 suspended particulate matter $(\mathrm{SM})\left(\mathrm{mg} \cdot \mathrm{L}^{-1}\right)$, and the organic matter $(\mathrm{OM})\left(\mathrm{mg} \cdot \mathrm{L}^{-1}\right)$ in the 147 bottom water were analyzed gravimetrically (Strickland and Parsons, 1972). The OM 148 were determined by the weight difference prior to dissolution with $1 \mathrm{~N} \mathrm{HCl}$ and $1 \mathrm{~N} \mathrm{H}_{2} \mathrm{O}_{2}$, 149 respectively (Carver, 1971).

$150 \quad$ 2.4. Granulometric analysis

$151 \quad$ Grain-size distributions for winter and summer were determined by sieving and 152 pipette methods (Müller, 1967), and the data was treated and classified according to Folk 153 and Ward's (1957) statistical parameters and Shepard's (1954) triangular diagram, 154 respectively.

2.4. Data analyses integration

Biological Resemblance matrices for winter and summer were constructed using

158 the Bray-Curtis similarity measure with a log $(x+1)$ transformation to normalize

159 foraminiferal counts. Species-abundance data were calculated for foraminiferal samples

160 (including taxa contributing $<0.45 \%$ or occurring in more than 13 samples) and subjected

161 to a Q-mode cluster analysis to define the foraminiferal assemblages. The Bray-Curtis 162 distance was used to measure the proximity between the samples, and Ward's linkage 163 method was used to arrange samples into a hierarchical dendrogram.

164 The foraminiferal data were analyzed using Non-metric Multidimensional Scaling 165 (MDS; Clarke, 1993) to emphasize the geometrical aspects of similarity and to visualize 166 complex data in a graphical environment. This approach recognizes patterns that might 167 not be apparent in a cluster analysis and provides a map of samples in which the 168 placement of samples, rather than simply representing their geographical location, 169 reflects the similarity of their biological communities and environmental patterns. The 170 MDS plots were created using PRIMER (Clarke \& Warwick, 1994). 

using the Euclidean distance with a log $(x+1)$ transformation to normalize data. The Biota and Environment matching analysis (BIOENV) was performed between biological and

174 environmental resemblance matrices with Spearman as the similarity rank correlation

175 method in both seasons to identify which variables are responsible for the foraminiferal 176 distribution.

177 Benthic foraminiferal relative abundance and environmental data on suspended matter (SM), organic matter $(\mathrm{OM})$, silicate $\left(\mathrm{SiO}_{4}{ }^{4}\right)$, nitrite $\left(\mathrm{NO}_{2}\right)$ nitrate $\left(\mathrm{NO}_{3}{ }^{-}\right)$, grain size

179 (mud and sand percentage) were used to generate contour maps using Surfer 8 (Golden software) to illustrate data.

\section{Results}

The relative abundance of foraminiferal species in the 65 winter samples and 55 summer samples are in the supplementary data (Tables 1 and 2). Depth, salinity, temperature, dissolved oxygen (Figure 3), suspension matter (SM), organic matter (OM), silicate $\left(\mathrm{SiO}_{4}^{-4}\right)$, nitrite $\left(\mathrm{NO}_{2}^{-}\right)$and nitrate $\left(\mathrm{NO}_{3}{ }^{-}\right)$of the bottom water (Figure 4), and the grain size of the sediments (Figure 5) in winter and in summer data are displayed in the supplementary data (Tables 3 and 4 ).

\subsection{Environmental setting}

Figure 3 shows the different water masses in our study sites: 1 . Cold, fresh, welloxygenated SASW, 2. Cold-upwelled SACW, 3. Warm-salty and less oxygenated STSW, and 4. Well oxygenated, cold, lower salinity CW which includes RdIP plume and other local river contribution with SASW.

195 Distribution of silicate and nitrate are similar to dissolved oxygen, salinity and 196 temperature, and reflect both continental and marine input on the shelf, and upwelling 197 with the presence of nutrient enriched austral waters and other processes of primary 198 production (Figure 4, Tables 3 and 4) close to the mouth of the Patos Lagoon. 
In austral winter, CW is under direct influence of the lower salinity RdIP plume in shallower stations (less than $50 \mathrm{~m}$ ). In summer, CW penetrates as far north as the

201 Albardão, and towards the south, we observed a decrease of salinity in the CW. Salinity

202 ranged from minimum 29.1UPS in summer, and 26.5UPS in winter, and 35.9UPS

203 maximum in both seasons. Temperature ranged from minimum of $5.5^{\circ} \mathrm{C}$ in winter and

$2046.4^{\circ} \mathrm{C}$ in summer and maximum varied from $19.6^{\circ} \mathrm{C}$ in winter and $24.3^{\circ} \mathrm{C}$ in summer.

205 In winter, bottom water oxygenation shows a clear separation, with oxygenated 206 waters (more than $5.4 \mathrm{~mL} \cdot \mathrm{L}^{-1}$ ) south of Rio Grande, and low oxygenated waters (less 207 than $4.4 \mathrm{~mL} \cdot \mathrm{L}^{-1}$ ) north of Rio Grande especially in the deepest parts (Table 3). In summer, 208 this pattern is less clear and oxygen concentration follows temperature patterns (Table $2094)$.

210 Suspended matter (SM) in the winter is highest $(107.6 \mathrm{mg} / \mathrm{L})$ in shallower stations 211 at Punta del Diablo and in deeper stations at Rio Grande and Solidão ( $57.2 \mathrm{mg} / \mathrm{L})$; in 212 summer, maximum concentrations occur in the deepest stations at Punta del Este 213 (59.0mg/L). The organic matter distribution in summer ( 0 to $41.6 \mathrm{mg} / \mathrm{L})$ and in winter (0$21428 \mathrm{mg} / \mathrm{L}$ ) follow the same pattern of SM. In summer, the maximum OM is also found at 215 Punta del Este, and in coastal stations is indicative of freshwater discharge with high 216 concentration of organic matter. Silicate, used here as a tracer of freshwater input is high 217 in Punta Medanos, Punta del Este, Albardão, Torres and Santa Marta Cape in the winter 218 ranging from 0 to $26.1 \mathrm{mg} / \mathrm{L}$; and in summer, maximum concentrations are observed in 219 Albardão and Punta del Este ranging from 0.9 to $18.7 \mathrm{mg} / \mathrm{L}$. Winter maximum nitrite 220 concentration is observed in Punta Medanos, Mar del Plata, and Albardão. In summer, 221 maxima are seen at Punta del Diablo and Santa Marta. In winter, highest $\mathrm{NO}_{2}$ 222 concentrations occur mainly in the deepest stations at Mar del Plata and Punta del Este 223 ranging from 0.5 to $1.5 \mathrm{mg} / \mathrm{L}$, and in summer, increase in nitrate is observed mainly in the 224 deepest stations of Punta Medanos and Plata River ranging from14.2 and 19.6 mg/L. Percentage of mud and sand for winter (Figure 5) shows that mud values are 226 usually $<2 \%$ closer to Patos Lagoon and higher values north of RdIP. On the other hand, 
227 percentage of sand is lower in specific points in the estuary of RdIP and south of Patos

228 Lagoon, while the northern transects have less sand in deeper sites. Percentage of sand

229 is higher (>80\%) closer to the coast in the northern transects. In winter, percentage of

230 gravel ranges from 0 to 46.7 , sand ranges from 53.3 to $100 \%$, and silt and clay totals are

$23112.1 \%$.

232

233 3.2 Foraminiferal Data

234 The mixohaline (same as 'brackish', which describes the delicate balance of 235 water that is neither fresh nor marine species) characteristic of freshwater occurs in 236 shallow samples close to sources of continental water discharge. We have divided the 237 mixohaline species based on the differences of their tests. Calcareous foraminiferal 238 species consist of Bolivina striatula, Buliminella elegantissima, Bulimina elongata, 239 Elphidium excavatum, E. poeyanum, and Pseudononion atlanticum (Figure 6) as 240 indicative of mixing of marine saline water with cooler and fresher water, derived from 241 continental runoff, and another fauna showing a less saline environment with marshes 242 and mangroves origin, featuring the agglutinated Ammobaculites exiguus, Arenoparrella 243 mexicana, Gaudryina exilis, Textularia earlandi and thecamoebians (truly freshwater, 244 transported organisms) (Figure 7).

245 Bolivina striatula occurs in the shallowest stations between RdIP $\left(35.8^{\circ} \mathrm{S}\right)$ and Rio 246 Grande $\left(31.5^{\circ} \mathrm{S}\right)$, in winter, abundance peaks reaches $16-40 \%$ occurs in Punta del Este 247 at $34.8^{\circ} \mathrm{S}$, Albardão at $32^{\circ} \mathrm{S}$, and Rio Grande near $31.5^{\circ} \mathrm{S}$. And in summer, the location 248 of the $40 \%$ occurrence peak is concentrate to the RdIP. In winter, Buliminella 249 elegantissima is dominant (35.3\%) in Punta del Diablo (33ㅇ) and in Albardão (33.7\%; $25032^{\circ} \mathrm{S}$ ), and in summer Albardão (40\%). In winter, $17.4 \%$ of Bulimina elongata is abundant 251 in Punta del Este, and in summer, the population peak is found in the RdIP $(30 \%)$.

252 Elphidium excavatum is observed in the shallowest stations in the winter of Punta del 253 Diablo (61\%), RdIP (16.4\%), and Rio Grande (27.6\%). 
Elphidium poeyanum is seen in Albardão (44.4\%) in winter and in the summer,

255 and the abundance of this species occurs in in the shallowest stations Punta del Diablo 256 (40.3\%), Albardão (43.5\%) and Rio Grande (49.1\%) and it is indicator of Patos lagoon 257 and Laguna freshwater discharge. In the winter, Pseudononion atlanticum is observed in 258 Punta del Este (25.8\%), Rio Grande (33.3\%), Torres (67.7\%), mainly in the shallowest 259 stations (less than $50 \mathrm{~m}$ ), and in summer, is concentrated in Rio Grande (40\%), indicator 260 of RdIP, Patos lagoon, and Laguna freshwater influence.

261 In winter, Ammobaculites exiguus occur in Punta del Este (10.2\%) at $65 \mathrm{~m}$ water 262 depth, while in summer, peak numbers (10.6\%) are observed in the deepest region of 263 RdIP at $95 \mathrm{~m}$. Arenoparrella mexicana occurs at 12\%, 9\% and 10\% abundance between 26464 and $87 \mathrm{~m}$ in the transects of Mar del Plata, Punta Medanos and Punta del Este, 265 respectively. In summer, this species is seen (11.1\%) in Albardão at $92 \mathrm{~m}$ and $40 \mathrm{~m}$ at 266 Punta del Este (14.6\%) also indicating RdIP freshwater influence.

267 The frequency of Gaudryina exilis is $7.8 \%$ in winter at $37 \mathrm{~m}$ water depth in 268 Albardão, and in the summer, their peak occurrence of $6.3 \%$ occurs at Punta Medanos 269 at $80 \mathrm{~m}$ water depth, Punta del Este $(28 \mathrm{~m})$ and Albardão $(64 \mathrm{~m})$ is indicative of 270 freshwater Patos lagoon influence.

271 Peak occurrence (50\%) of Textularia earlandi is at Punta del Este at $22 \mathrm{~m}$ water 272 depth in the winter, and in the summer (7.1\%) in Punta Medanos at $23 \mathrm{~m}$ is indicative of 273 RdIP and Laguna freshwater influence.

274 Thecamoebians tests have been observed mainly in the winter at depths of $64 \mathrm{~m}$ 275 in Punta del Este. The influence of the fluvial discharge is observed as deep as $92 \mathrm{~m}$ in 276 the Albardão region, indicating influence of freshwater discharge from Patos Lagoon over 277 the shelf is even more intense in summer. These microorganisms are indicative of RdIP 278 and Patos lagoon freshwater influence.

279 The main benthic Foraminifera species Pseudononion atlanticum, Bolivina 280 striatula, Buliminella elegantissima, Bulimina elongata, Elphidium excavatum, E. 
281

282 283

284

285

286

287

288

289

290

291

292

293

294

295

296

297

298

299

300

301

302

303

304

305

306

307

308

poeyanum, Ammobaculites exiguus, Arenoparrella mexicana, Gaudryina exilis, Textularia earlandi, and thecamoebians species found in this study are shown in Plate 1.

\subsection{Data correlation}

A cluster analysis based on the major total species (live + dead specimens) from winter reveal the existence of seven groups of stations containing similar foraminiferal composition (Fig. 8). The MDS analysis shows the foraminiferal indicator species (Fig. 9) for the seven groups. It was possible to observe that Group I has Discorbis williamsoni as the characteristic species of stations 4 and 16 , and it is located on the inner shelf, south of RdIP. Group II has Ammonia beccarii as the characteristic species of the shallower stations closer to the inner shelf of RdIP (stations 0 and 32). Group III has Buliminella elegantissima, Bolivina striatula, and Elphidium poyeanum as indicator species in the shallower stations, indicating inner shelf environments influenced by Patos Lagoon input (stations $30,50,48,49,17$, and 33). Group IV has Buccella peruviana as the indicator species of colder water in outer shelf stations of RdIP (stations 29, 11, 12 , $27,13,31,22,28,5,3,19,21,26,2,14,1,15,34,62,20,6,18)$. Group $\vee$ has Cassidulina subglobosa as its indicator species in only one station (68) in the inner shelf north of Patos Lagoon. Group VI is dominated by B. striatula and Elphidium poyeanum at stations $36,37,47,69,46$, and 70 mostly indicating the influence of Patos Lagoon, Mirim Lagoon and Laguna Estuarine System river discharge in the inner and middle continental shelf. Group VII has stations from inner to outer shelf, in the northern part of our study area (stations 52, 64, 54, 79, 80, 81, 58, 59, 65, 60, 66, 71, 72, 74, 42, 73, 61, $83,38,45,53,43,44,82,51$ and 67 ), and the presence of Hanzawaia boueana and Bulimina marginata in those stations indicates the influence of warmer waters from STSW rather than freshwater influence from Laguna Estuarine System and Itajaí Açu River. Station 38 has the deepest and southernmost occurrence of Hanzawaia boueana and Bulimina marginata in the Mirim Lagoon. 
310 the existence of five groups of stations (Fig. 10). The MDS analysis shows the

311 foraminiferal indicator species (Fig. 11) for the five groups.

312 Group I has Discorbis williamsoni and Ammonia beccarii as characteristic species

313 in shallow stations (stations 0 and 20) on the inner shelf at the RdIP. Group II has Buccella

314 peruviana (cold-water tolerant), Discorbis williamsoni, Buliminella elegantissima, and

315 Elphidium poyeanum in stations $4,15,33,37,14,22,21,34,19,2,13,16,24,23,31$,

31632,1 , and 17 from the inner to middle shelf, which indicate the presence of mixing river

317 discharge of the RdIP, with the SASW cold water mass. Group III has also Buliminella

318 elegantissima and Elphidium poyeanum in the northern part of the inner shelf at the RdIP,

319 indicating the influence of the Patos Lagoon (stations 48, 49, 63, 64, 38 and 50). Group

320 IV has Bulimina marginata and Bolivina striatula as indicator species, suggesting mixture

321 of STSW and freshwater from both Mirim and Patos lagoons deeper on the shelf (stations

$32230,40,60,51,52,53,41$ and 42). Group V records Bolivina striatula, Hanzawaia

323 boueana, Uvigerina peregrina, Buliminella elegantissima and Cassidulina subglobosa as

324 indicator species of inner to outer shelf, in the northern part of study site, with the limit of

325 their occurrence being Patos Lagoon $(66,88,79,57,87,5,12,6,73,58,59,78,39,62$,

$32690,76,65,89,61,75$, and 77 ). Only stations 5,6 , and 12 located on the outer shelf of

327 the southernmost limit of our study site shows the penetration of STSW in the deeper

328 parts of the RdIP in summer.

329 Figure 12 shows a summary of the interaction and mixing between warm (STSW)

330 and cold (SASW) water masses for austral winter and summer and associated faunal

331 changes. These changes primarily relate to the distribution of freshwater foraminiferal

332 species. This finding confirms the BIOENV results that indicate depth, salinity, and

333 temperature are the most important variables along the coast in controlling faunal

334 assemblages. Freshwater runoff in this shelf environment plays an important role in the

335 establishment of foraminiferal distribution from inner to outer shelf. The areas of water

336 mass mixing in winter form an elongate freshwater plume in the inner shelf closer to the 
337 coast, indicating the presence of freshwater through flow from inner to the outer shelf. In

338 the summer, plume is more concentrated south of Patos Lagoon, while shoreward of

339 Mirim Lagoon it occurs in the middle and in the outer shelf.

340 area that experiences influence of freshwater from the RdIP and local discharge from other sectors, including the Itajaí Açu system, Laguna Estuarine System, and Patos

345 Lagoon over the sediments of continental shelf. We also show that CW is a cool, marine,

346 less saline water mass influenced by freshwater discharge and can be traced to water 347 depths of $50 \mathrm{~m}$ agreeing with Burone et al., (2013) who through a multiproxy study 348 between the RdIP and the adjacent Southwestern Atlantic inner shelf assessed the sediment footprint of river vs. marine influence.

The distribution of silicate and nitrate associated with dissolved oxygen, salinity and temperature as tracer of continental input reveals the strong fresh water from RdIP, and local continental contributions along the coast agreeing with the biological findings. Terrestrial and marine input on the shelf are regeneration processes from river inputs, flocculation, upwelling, and primary production close to the mouth of Patos Lagoon, but also recorded in other local smaller sources as Itajaí-Açú River, and Laguna Estuarine 356 System.

In winter, high silicate values are associated with low salinity, confirming substantial influence of freshwater on the continental shelf, while the concentration of nitrogenous compounds is indicative of open marine influence. Nutrient, dissolved oxygen, and suspended matter distributions show fresh water discharges close to the

361 coast and to RdIP estuary. Nutrient and dissolved oxygen concentrations of deep and

362 bottom waters in the Guinea and Angola Basins have showed that silicate enrichment 363 associated with oxygen deficiencies at about 4000m depth (van Benenkom, 1996; van 364 Benekom and Berger, 1984) is due to the remineralization of terrestrial debris, mainly 
365 composed of clay and organic matter. On the other hand, close to the river mouth of the

366 Rhône (Gulf of Lion, NW Mediterranean), the limited oxygen penetration in the sediment

367 combined with hydro-sedimentary processes on a river-dominated shelf constitute

368 stressful conditions for foraminiferal faunas and is dominated by opportunistic species

369 (Goineau et al., 2011).

370 The general trends in paralic foraminiferal faunas around the world are 371 decreasing in diversity and decreasing in calcareous forms passing to agglutinated 372 species landward, in relation with decreasing $\mathrm{pH}$ and decreasing availability of calcium 373 carbonate (review in Murray 1973, 1991; Debenay 1990; Hayward and Hollis 1994).

374 Marine sediments show fauna transition on the mouths of the RdIP, Itajaí Açu system, 375 Laguna Estuarine System, and Patos Lagoon, where calcareous benthic foraminiferal 376 species: Pseudononion atlanticum (Cushman, 1936), Bolivina striatula (Cushman, 377 1922), Buliminella elegantissima (d'Orbigny, 1839), Bulimina elongata (d'Orbigny, 1826), 378 Elphidium excavatum (Terquem, 1875), and E. poeyanum (d'Orbigny, 1826) are replaced 379 by agglutinated Ammobaculites exiguus (Cushman \& Brönnimann, 1948), Arenoparrella 380 mexicana (Kornfeld, 1931), Gaudryina exilis (Cushman \& Brönnimann, 1948), Textularia 381 earlandi (Parker, 1952), and thecamoebians (genera Difflugia and Centropyxs) in more 382 restricted environments. These species were established as either mixohaline, or 383 freshwater species (Scott and Medioli, 1978). Their distribution are limited by water depth 384 and continental water discharge (Eichler et al. 2012), shown in overview, however the 385 present study would like to further discuss in detail the freshwater tolerant fauna that is 386 showing opportunism traits on marine sediments along the shelf and its implication for 387 the potential pollution that may accumulate.

388 Bolivina striatula is an opportunist characteristic of mangroves of Puerto Rico 389 (Culver, 1990, Debenay et al., 1998), and Buliminella elegantissima mangroves of

390 Columbia (Boltovskoy and Hincapié de Martinez, 1983; Otvos, 1978). Eutrophication has

391 markedly changed the distribution of the opportunistic and tolerant species Bulimina 392 elongata in Amvrakikos Gulf, in northwestern Greece (Naeher et al., 2012). These 
393 buliminids prevail in muds associated with low hydrodynamics, low oxygenation, and

394 high organic matter on the Northern Gulf of Cadiz Continental Shelf (Mendes et al., 2012;

395 Garcia-Gallardo et al., 2017). In our study, these species indicate the presence of low

396 hydrodynamics with organic enrichment accumulation in at least four sites on the shelf.

397 Elphidium excavatum is originally from the outer paralic system (Martin and Liddell, 398 1988) and is found in mangrove environments in Equator by Boltovskoy and Vidarte 399 (1977), and in New Zealand (Gregory, 1973; Hayward et al., 1996, 1999). Goldstein 400 (1976) also found Elphidium poeyanum in mangrove sediments of the Bahamas. The 401 presence of this species in our continental shelf shows that there is mixohaline influence 402 and flocculation process occurring. Pseudononion atlanticum is also an opportunist low 403 oxygen-tolerant species (Blackwelder et al., 1996) and its distribution may indicate 404 hypoxia in at least three areas over the studied continental shelf. Boltovskoy et al. (1980) 405 describe Bolivina striatula, Buliminella elegantissima, Elphidium excavatum, E. gunteri, 406 and Elphidium spp. as marine euryhaline, opportunists tolerant to less saline waters of 407 the Patos Lagoon and RdIP. On the other hand, Eichler et al. (2007) found Buliminella 408 elegantissima, Elphidium excavatum, and E. poeyanum in polyhaline (a salinity category 409 term applied to water bodies with a salinity of between 18 and 30 PSU) water where 410 sand-silt sediments of Bertioga estuarine channel are enriched with organic carbon and 411 sulfur.

412 The agglutinated Ammobaculites exiguus, Arenoparrella mexicana, Gaudryina 413 exilis, Textularia earlandi are inner paralic environments species (Martin and Liddell, 414 1988). Together with the presence of thecamoebians indicate input from freshwater 415 runoff or ground water, which high numbers usually mark strong inflow from a river (Scott 416 et al., 2001). Both the agglutinated and the thecamoebians species are characteristic of 417 the estuary of the RdIP and Patos Lagoon and their occurrence in shelf sediments 418 strongly suggests freshwater influence. Ammobaculites exiguus has been found in the 419 mangroves of Florida and the Bahamas (Phleger, 1965), New Zealand (Gregory, 1973; 420 Hayward et al., 1996, 1999), and Arenoparrella mexicana in the mangroves of Brazil 
421 (Zaninetti et al., 1977; 1979; Hiltermann et al., 1981; Scott et al., 1990) and Equator 422 (Boltovskoy and Vidarte, 1977). Bolivina sp, and Arenoparrella mexicana are typical of 423 the oligohaline and mesohaline mangrove-fringe environment (5-18 psu) of Bertioga 424 Channel in SP, Brazil (Eichler et al., 2007). Their presence indicate very saline restricted 425 environments in the inner shelf. Textularia earlandi is also found in mangrove sediments 426 from Colombia (Boltovskoy and Hincapie de Martinez, 1983) but is not restricted to this 427 environment. This species has been found in the inner shelf worldwide and its presence 428 is thought to be more related to the higher grain sizes and high hydrodynamics than 429 freshwater itself. Gaudryina exilis has been found in mangroves of Senegal (Debenay et 430 al., 1989) and Puerto Rico (Culver, 1990) and thecamoebians in Ecuador (Boltovskoy 431 and Vidarte, 1977), Trinidad and South Caribbean (Todd \& Brönniman, 1957; Saunders, 432 1957, 1958; Drooger \& Kaasschieter, 1958). Similar results have been recently 433 documented in the Gulf of Guinea, Eastern South Atlantic, Nigeria (Fajemila and Langer, 434 2016) and in Gabon (Langer et al., 2016a and b) showing similarities across the Atlantic, 435 specifically between the western coast of Brazil and the Gulf of Guinea states.

436 Data from BIOENV indicate that the responsible variables for the foraminiferal 437 distribution are depth, salinity, temperature, oxygen, grain size, $\mathrm{SM}, \mathrm{OM}, \mathrm{SiO}_{4}, \mathrm{NO}_{2}$, and $438 \mathrm{NO}_{3}$ in this order of importance. Most freshwater indicators were found on shallower 439 sites, where salinity was lower, and percentage of mud suggests a depositional site 440 rather than erosional regime at those sites. On the other hand, northern transects have 441 less sand in deeper sites, and more sand closer to the coast. These indicate the 442 presence of low hydrodynamics with organic enrichment accumulation in at least four 443 sites on the shelf, which includes RdIP and other local input as Itajaí-Açú River, Laguna 444 estuarine system and Patos Lagoon over the continental shelf.

445 The cluster and MDS analysis based on the major total species showed some 446 similarities and differences from winter to summer. There is presence of Discorbis 447 williamsoni and Ammonia beccarii on shallower stations of inner shelf, south of RdIP. In 448 winter, Buliminella elegantissima, Bolivina striatula, and Elphidium poyeanum are 
449 indicators of shallower stations of inner shelf influenced by Patos Lagoon input. Buccella

450 peruviana is indicator of colder water in outer shelf stations shelf of RdIP. In summer,

451 however, B. peruviana, Discorbis williamsoni, Buliminella elegantissima, and Elphidium

452 poyeanum in the inner to middle shelf, indicate the presence of mixing of river discharge

453 of the RdIP and SASW, the cold water mass. Buliminella elegantissima and Elphidium

454 poyeanum in the northern part of the inner shelf at the RdIP, indicate the influence of the

455 Patos Lagoon. Environments dominated by B. striatula and Elphidium poyeanum

456 indicate the influence of Patos Lagoon, Mirim Lagoon and Laguna Estuarine System

457 river discharge in the inner and middle continental shelf. In the northern part of our study

458 area, from inner to outer shelf, the presence of Hanzawaia boueana and Bulimina

459 marginata in those stations indicates the influence of warmer waters from STSW rather

460 than freshwater influence from Laguna Estuarine System and Itajaí Açu River. The

461 presence of Bulimina marginata and Bolivina striatula suggest mixture of STSW and

462 freshwater from Patos lagoon in deeper parts of the shelf. In summer, the limit of their

463 occurrence is Patos Lagoon, which the southernmost limit of our study site shows the

464 penetration of STSW in the deeper parts of the RdIP

465

466

467

\section{Conclusions}

Distribution of silicate and nitrate associated with dissolved oxygen, salinity and temperature show regeneration processes occurring due to the presence of river inputs, upwelling, and other process of primary production in four sites on the shelf: PPW and other local input as Itajaí-Açú River, Laguna Estuarine System and Patos Lagoon over 471 the continental shelf.

472 The responsible variables for the foraminiferal distribution are depth, salinity, 473 temperature, oxygen, grain size, $\mathrm{SM}, \mathrm{OM}, \mathrm{SiO}_{4}, \mathrm{NO}_{2}$, and $\mathrm{NO}_{3}$ in this order of 474 importance. Most freshwater indicators were found on shallower sites, where salinity was 475 lower, and percentage of mud suggests a depositional site rather than erosional regime 476 at those sites. These more restrict environments indicate more freshwater influence and 
477 the presence of agglutinated Ammobaculites exiguus, Arenoparrella mexicana, 478 Gaudryina exilis, Textularia earlandi, and the thecamoebians, which are organisms of 479 continental origin, estuaries and salt marshes, and are present are under more influence 480 of anthropogenic activities from land. The abovementioned species are biological 481 indicators of freshwater influence over the continental shelf.

482

\section{Acknowledgements}

We thank CAPES (Coordenação de Aperfeiçoamento de Pessoal de Nível 485 Superior) through the Project "Processos oceanográficos na quebra da plataforma 486 continental do nordeste brasileiro: fundamentos científicos para o planejamento espacial 487 marinho (Edital Ciências do Mar $2 n^{\circ}$ 43/2013, 23038.004320/2014-11) for the Post Doc 488 Fellowship at Universidade Federal do Rio Grande do Norte (UFRN-Brazil). We are 489 grateful to CAPES for research funding (award PVE 151-2012, AUXPE 242/2013). The 490 PLATA cruises and laboratory work were financially supported by the U.S. Office of Naval 491 Research (ONR, Grant N00014-02-1-0295), the Inter-American Institute for Global 492 Change Research (IAI, Grant SACC/CRN-061), and the Fundação de Amparo à 493 Pesquisa do Estado de São Paulo (FAPESP, Grant 2004/01950-3). We acknowledge the 494 help of DHN (Brazil), SHN (Argentina), and SOHMA (Uruguay) in the marine operation. 495 SeCIRM provided fuel for the Summer Cruise. The Argentinean oceanographic vessel 496 Ara Puerto Deseado and the Brazilian oceanographic vessel Antares gave support with 497 sample collection. The authors wish to thank Christofer Barker from Eco-Logic Project 498 for the English review.

\section{References}

501

502 Berbery, E. and V.R. Barros, 2002: The Hydrologic Cycle of the La Plata Basin in South 503 America. J. Hydrometeor., 3, 630-645, doi: 10.1175/1525$5047541(2002) 003<0630:$ THCOTL $>2.0 . C O ; 2$. 
505 Blackwelder, P., Hood, T., Alvarez-Zarikian, C., Nelson, T.A., and McKee, B., 1996.

506 Benthic Foraminifera from the NECOP study area impacted by the MR plume and 507 seasonal hypoxia: Quaternary International, v. 31, p. 19-36.

508 Boltovskoy, E., and Vidarte, L.M., 1977. Foraminiferos de la zona de manglar de 509 Guayaquil (Ecuador). Hidrobiologia, 5: 31-40.

510 Boltovskoy, E.; Giussani, G.; Watanabe, S. \& Wright, R., 1980. Atlas of benthic shelf 511 foraminifera of the Southwest Atlantic. Dr. W. Junk. 147 p.

512 Boltovskoy, E., and Hincapie de Matinez, S., 1983. Foraminiferos del manglar de Tesca, 513 Cartagena, Colombia. Revista Espanola Micropaleontologica, 15: 205-220.

514 Braga, E.S., Chiozzini, V.G., Berbel, G.B.B., Maluf, J.C.C., Aguiar, V.M.C., Charo, M., 515 Molina, D., Romero, R. and Eichler, B.B., 2008. Nutrients distribution over the 516 Southeastern South Atlantic continental shelf from Mar del Plata (Argentina) to Itajaí 517 (Brazil): Winter-summer aspects. Continental Shelf Research, vol. 28, p. 1649-1661.

518 Burone, L., Ortega, L., Franco-Fraguas, P., Mahiques, M., García-Rodriguez, F., 519 Venturini, N., Marin, Y., Brugnoli, E., Nagai, R., Muniz, P. and Bícego, M., 2013. A multiproxy study between the RdIP and the adjacent South-Western Atlantic inner shelf to assess the sediment footprint of river vs. marineinfluence. Continental shelf research, 55, pp.141-154.

Clarke, K. R., 1993. Non-parametric multivariate analyses of changes in community structure: Australian Journal of Ecology, v. 18, p. 117-143.

Clarke, K. R., and Warwick, R. M., 1994. Change in Marine Communities: An Approach to Statistical Analyses and Interpretation: Natural Environment Research Council, Plymouth, UK, $144 \mathrm{p}$.

Culver, S.J., 1990. Benthic foraminifera of Puerto Rican mangrove-lagoon systems: potential for paleoenvironmental interpretations. Palaios, 5: 34-51.

Debenay, J.P., Pages, J., and Diouf, P.S., 1989. Ecological zonation of the hyperhaline estuary of the Casamance river (Senegal): foraminifera, zooplankton and abiotic variables. Hydrobiologia, 174: 161-176

Debenay, J. P., Bicchi, E., Goubert, E., \& Du Châtelet, E. A. 2006. Spatio-temporal 534 distribution of benthic foraminifera in relation to estuarine dynamics (Vie estuary, Vendée, W France). Estuarine, Coastal and Shelf Science, 67(1-2), 181-197. 
Depetris, P. J. and J. E. Paolini., 1991. Biogeochemical Aspects of South American Rivers: The Paraná and the Prinoco. Eds: Degens, E.T., Demp, S. J. E. Richey. En: Biogeochemistry of Major World Rivers, Scope 42, John Wiley \& Sons, New York, pp 165-194.

Drooger, C.W., and Kaaschieter, J.P.H., 1958. Foraminifera of the Orinoco-TrinidadParia shelf, v. 4 of Reports of the Orinoco Shelf Expedition. Konink. Nederlandse Akademie Wetenschapen, Afd. Natuurk. Verh., 1st Reeks, 22: 1108

Eichler, P.P.B., Eichler, B.B., de Miranda, L.B., Rodrigues, A. R., 2007. Modern foraminiferal facies in a subtropical estuarine channel, Bertioga, São Paulo, Brazil. The Journal of Foraminiferal Research, 37(3), 234-247.

Eichler, P.P.B., Sen Gupta, B.K., Eichler, Beatriz Beck; Braga, E. S., Campos, Edmo José. 2008. Benthic foraminiferal assemblages of the South Brazil: Relationship to water masses and nutrient distributions. Continental Shelf Research, v. 28, p. 16741686.

Eichler, P.P.B.; Rodrigues, A.R.; Eichler, B.B.; Braga, E.S.; Campos, E.J.D. 2012. Tracing latitudinal gradient, river discharge and water masses along the subtropical South American coast using benthic Foraminifera assemblages. Brazilian Journal of Biology (Impresso), v. 72, p. 723-759.

Eichler, P.P.B., Pimenta, F. M., Eichler, B.B., Vital, H., 2014. Living Bulimina marginata in the SW Atlantic continental margin: Effect of the Subtropical Shelf Front and South Atlantic Central Water. Continental Shelf Research, 89: 88-92.

Eichler, P. P., Pimenta, F. M., Eichler, B. B., Vital, H., 2016. Living benthic foraminiferal species as indicators of cold-warm water masses interaction and upwelling areas. Continental Shelf Research 116: 116-121.

Ellis B.F., Messina A., 1940. Catalogue of Foraminifera, American Museum of Natural History, Supplements.

Farooqui, A., Kumar, A., and Swindles, G.T. 2012. Thecamoebian communities as proxies of seasonality in Lake Sadatal in the Ganga-Yamuna Plains of North India. Palaeontologia Electronica Vol. 15, Issue 1; 3A, 19p; palaeoelectronica.org/content/2012-issue-1-articles/117-thecamoebian-community

Fatela, F. and Taborda, R., 2002. Confidence limits of species proportions in microfossil assemblages. Marine Micropaleontology, 45:169-174. 
571 Fajemila, O.T. and Langer, M.R. (2016). Ecosystem indicators: Foraminifera, 572 Thecamoebians and Diatoms from the Ologe Lagoon, Nigeria. Revue de 573 Micropaléontologie, 59 (4): 397-407.

574 Franco-Fraguas, P., Burone, L., Mahiques, M., Ortega, L., Carranza, A., 2016. Modern

Goineau, A. Fontanier, C. Jorissen, F.J. Lansard, B. Buscail, R. Mouret, A. Kerhervé, P. Zaragosi, S. Ernoult, E. Artéro, C. Anschutz, P. Metzger, E. Rabouille, C., 2011. Live (stained) benthic foraminifera from the Rhône prodelta (Gulf of Lion, NW Mediterranean): Environmental controls on a river-dominated shelf, Journal of Sea Research, Volume 65, Issue 1, January, Pages 58-75, ISSN 1385-1101, http://dx.doi.org/10.1016/j.seares. 2010.07.007.

Grasshoff, K., Ehrhmardt, M. and Kremling, K., 1983. Methods of seawater analysis. 2nd. ed. Weinhein: Verlag Chimie. 419 p.

Gregory, M.R., 1973. Benthonic foraminifera from a mangrove swamp, Whangaparapara, Great Barrier Island. Tane 19:193-203.

Hayward, B. W., Grenfell, H. R., Cairns, G. \& Smith, A., 1996. Environmental Controls on Benthic Foraminifera and Thecamoebian Associations in a New Zealand Tidal Inlet. Journal of Foraminiferal Research, 26: 50-171.

Hayward, B.W., H.R. Grenfell, C.M. Reid, K.A. Hayward, B., 1999a. Recent New Zealand shallow-water benthic foraminifera: taxonomy, ecologic distribution, biogeography and use in paleo environmental assessment. Monograph No. 21. Institute of Geological and Nuclear Sciences, Lower Hutt, New Zealand

Hiltermann, H., Bronnimann, P., Zaninetti, L., 1981. Neue Biozonosen in den sedimenten der mangrove bei Acupe, Bahia, Brasilien. Notes du Laboratoire de Paléontologie, Université de Genève, 8: 2-6.

Jones, R.W., 2006. Applied palaeontology. Cambridge: Cambridge University Press, $434 \mathrm{pp}$.

Langer, M.R., Fajemila, O.T., and Mannl, S. (2016). Assemblages of recent intertidal mangrove foraminifera from the Akanda National Park, Gabon: Sea level proxies preserved in faunal assemblages Neues Jahrbuch für Geologie und Paläontologie - Abhandlungen, 281(3): 327-338. 
604 Langer, M.R., Mouanga, G.H., and Fajemila, O.T. (2016). Shallow-water nearshore 605 benthic foraminifera assemblages from Gabon Micropaleontology, 2016.

606 Martin, R.E., Liddell, W.D., 1988. Foraminiferal biofacies on a north coast fringing reef 607 (1-75 m), Discovery Bay, Jamaica. Palaios, 3: 298-314.

608 Martins, M.V.A., Quintino, V., Tentúgal, R.M., Frontalini, F., Miranda, P., Laut, L.L.M., 609 Martins, R., Rodrigues, A.M., 2015. Characterization of bottom hydrodynamic 610 conditions on the central western Portuguese continental shelf based on benthic 611 foraminifera and sedimentary parameters. Marine Environmental Research, 109, 612 52-68. DOI:10.1016/j.marenvres.2015.06.006

613 Mendes, I., Dias, J.A., Schönfeld, J., and Ferreira, Ó., 2012. Distribution of living benthic 614 foraminifera on the northern Gulf of Cadiz continental shelf. Journal of Foraminiferal $615 \quad$ Research, 42:18-38.

616 Muelbert, J.H. and Sinque, C., 1996. Distribution of bluefish (Pomatomus saltatrix) 617 larvae along the continental shelf off southern Brazil. Marine and Freshwater $618 \quad$ Research, 47(2), pp.311-314.

619 Murray, J.W., 2001. The niche of benthic foraminifera, critical thresholds and proxies. 620 Marine Micropaleontology, 41, 1-7.

621 Murray, J.W., 2006. Ecology and Applications of Benthic Foraminifera. Cambridge $622 \quad$ University Press, New York, 426 p.

623 Naeher, S., Geraga, M., Papatheodorou, G., Ferentinos, G., Kaberi, H., Schubert, C.J., 624 2012. Environmental variations in a semi-enclosed embayment (Amvrakikos Gulf, 625 Greece)-reconstructions based on benthic foraminifera abundance and lipid 626 biomarker pattern. Bio geosciences, 9(12), p.5081.

627 Phleger, F.B., 1965. Patterns of marsh foraminifera, Galveston Bay, Texas. Limnology 628 and Oceanography, 10: R 169-R184

629 Piola, A. R., R. P. Matano, E. D. Palma, O. O. Möller Jr., and E. J. D. Campos., 2005. 630 The influence of the Plata River discharge on the western South Atlantic shelf, 631 Geophys. Res. Lett., 32, L01603, doi: 10.1029/2004GL021638.

632 Saunders, J.B. 1957. Trochamminidae and certain Lituolidae (Foraminifera) from the 633 Recent brackish-water sediments of Trinidad, British West Indies. Smithsonian 634 Miscellaneous Collections, 134: 1-16. 
635

636

637

638

640
Saunders, J.B., 1958. Recent foraminifera of mangrove swamps and river estuaries and their fossil counter-parts in Trinidad. B.W.I. Smithsonian Miscellaneous Collections, 134: 1-16.

Scott, D.S., Medioli, F.S. 1978. Vertical zonations of marsh foraminifera as accurate indicators of former sea-level. Nature 1978/04/06/ online

Scott, D.B., Schafer, C.T., and Medioli, F.S., 1980. Eastern Canadian estuarine foraminifera: A framework for comparison: Journal of Foraminiferal Research, v. 10, no. 3, p. 205-234.

Scott, D.B., Schnack, E.J., Ferrero, L., Espinosa, M., and Barbosa, C.F., 1990. Recent marsh foraminifera from the east coast of South America: comparison to the Northern Hemisphere. In: Hemleben et. al. (eds): Paleoecology, Biostratigraphy, Paleooceanography, and Taxonomy of agglutinated foraminifera, Kluwer Acad. Publ., Netherlands, Proceedings of NATO ASI/Series C, 327: 717-738

Strickland, J.D.H. and Parsons, TR., 1972. A Practical Handbook of Seawater Analysis. 2nd ed. Ottawa: Fisheries Research Board of Canada. 310 p. Bulletin, no. 169.

Sunye, P.S. and Servain, J., 1998. Effects of seasonal variations in meteorology and oceanography on the Brazilian sardine fishery. Fisheries Oceanography, 7(2), pp.89-100.

Todd, R., and Brönnimann, P., 1957. Recent foraminifera and Thecamoebian from the eastern Gulf of Paria. Cushman Foundation for Foraminiferal Research, Special Publication, 3: 1-43.

Van Bennekom, A.J., 1996. Silica signals in the South Atlantic. In: Wefer, G., Berger, W.H., Siedler, G., Webb, D.J. (Eds.), The South Atlantic - Present and Past Circulation. Springer,Berlin, pp. 345-354.

Van Bennekom, A.J., Berger, G.W., 1984. Hydrography and silica budget of the Angola Basin. Neth. J. Sea Res. 17, 149-200.

Zaninetti, L. 1979. L'étude des foraminifères des mangroves actuelles: réflexion sur les objectifs et sur l'état des connaissances. Archives des Sciences deGenève, 32: 151-161.

Zaninetti, L., Brönnimann, P., Beurlen, G., and Moura, J.A. 1977. La mangrove de Guaratiba et la baie de Sepetiba, état de Rio de Janeiro, Brésil: Foraminifères et écologie. Archives des Sciences de Genève, 30: 161-178 
668 Figure 1: Water masses and fronts (STSW, STSW, STSF) (modified from Eichler et al., 669 2016).

670 Figure 2: Transects from south to north are as follows: (T1) Mar del Plata, (T2) Punta 671 Medanos, (T3) Plata River, (T4) Punta del Este, (T5) Punta del Diablo, (T6) Albardão, 672 (T7) Rio Grande, (T8) Solidão, (T9) Torres, (T10) Santa Marta, and (T11) Itajaí collected 673 in winter and summer.

674 Figure 3: Bottom hydrographical data: salinity (PSU), temperature $\left({ }^{\circ} \mathrm{C}\right)$, oxygen $\left(\mathrm{mL} \cdot \mathrm{L}^{-1}\right)$ 675 and Coastal zone water (CW), Subantartic Shelf Water (SASW), Subtropical Shelf Water 676 (STSF) (modified from Eichler et al., 2008).

677 Figure 4: Distribution maps of the dissolved and particulate matter from bottom water: 678 total suspension matter $(\mathrm{SM})$, suspended organic matter $(\mathrm{OM})$, silicate $\left(\mathrm{SiO}_{4}{ }^{4-}\right)$, nitrite $679\left(\mathrm{NO}_{2}{ }^{-}\right)$and nitrate $\left(\mathrm{NO}_{3}{ }^{-}\right)$.

680 Figure 5: Percentage of mud and sand from the winter samples.

681 Figure 6: Relative abundance of Bolivina striatula, Buliminella elegantissima, Bulimina 682 elongata, Elphidium excavatum, Elphidium poeyanum, Pseudononion atlanticum and the 683 occurrence of freshwater influence (modified from Eichler et al., 2012).

684 Figure 7: Relative abundance of Ammobaculites exiguus, Arenoparrella mexicana, 685 Gaudryina exilis, Textularia earlandi and thecamoebians species (modified from Eichler 686 et al., 2012).

687 Figure 8: Cluster analysis based on the major total species (live + dead specimens) from 688 winter.

689 Figure 9: MDS analysis and the foraminiferal indicator species from winter.

690 Figure 10: Cluster analysis based on the major total species from summer.

691 Figure 11: MDS analysis and the foraminiferal indicator species from summer.

692 Figure 12: Summary of the interaction and mixing between warm (STSW) and cold-water 693 masses (SASW) for austral winter and summer.

694

695 Supplementary data 
696 Table 1: Relative abundance of foraminiferal species and total number of individuals in 697 winter 2003.

698 Table 2: Relative abundance of foraminiferal species and total number of individuals in 699 summer 2004.

700 Table 3 (supplementary data): Information on geographical location, depth, salinity, 701 temperature, oxygen, suspended matter (SM), organic matter (OM), SIO4, NO2, NO3

702 and percentage of gravel, sand, silt and clay for the austral winter.

703 Table 4 (supplementary data): Information on geographic location, depth, salinity, 704 temperature, oxygen, suspended matter (SM), organic matter (OM), $\mathrm{SIO}_{4}^{4-}, \mathrm{NO}_{2}^{-}, \mathrm{NO}_{3}^{-}$ 705 and percentage of gravel, sand, silt and clay for the austral summer.

706 Plate: 1. Bolivina striatula, Buliminella elegantissima, Elphidium poeyanum, 707 Pseudononion atlanticum, Elphidium excavatum, Ammobaculites exiguus, Gaudryina 708 exilis, Arenoparrella mexicana, Textularia earlandi, Thecamoebians.

709

710 


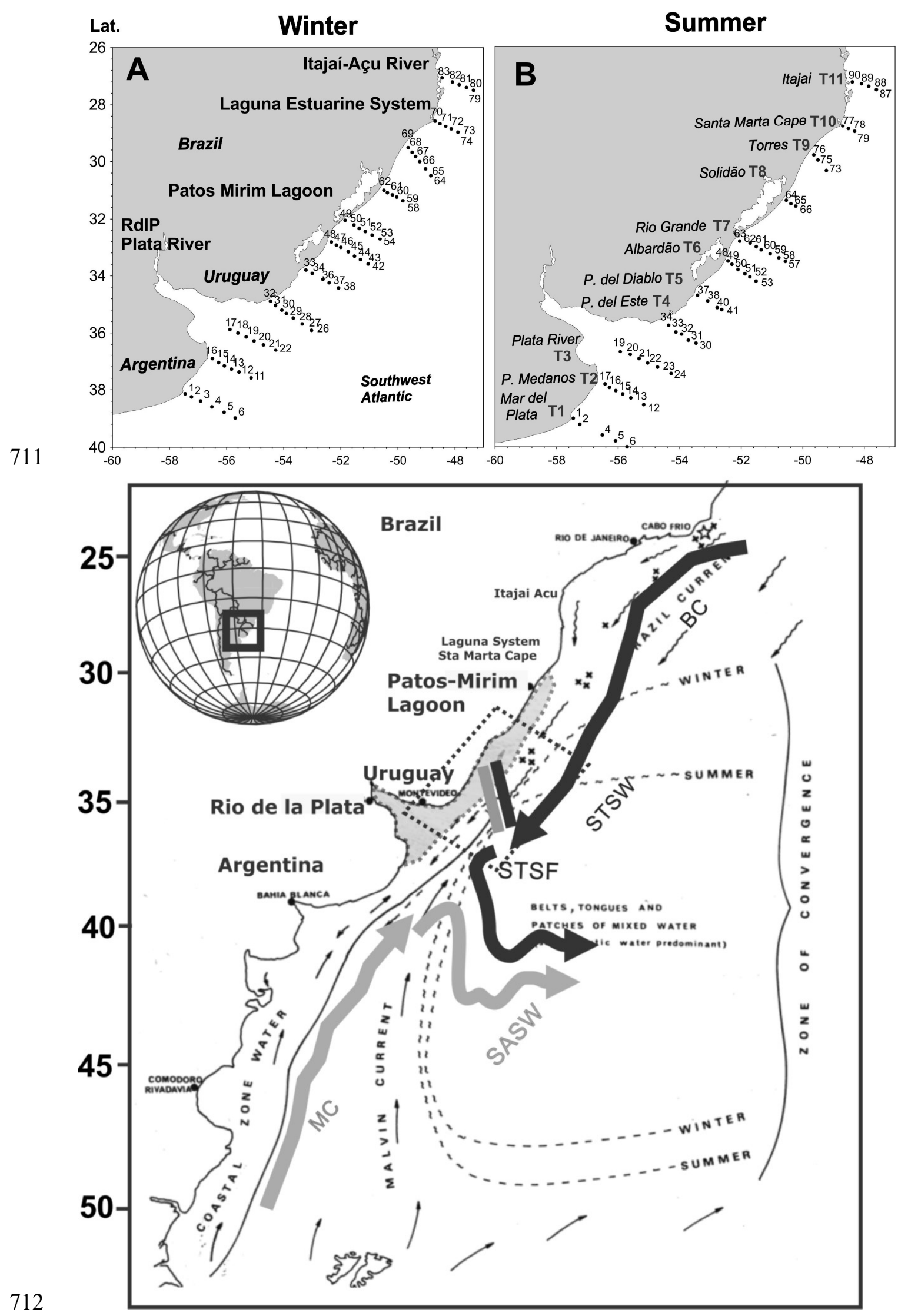




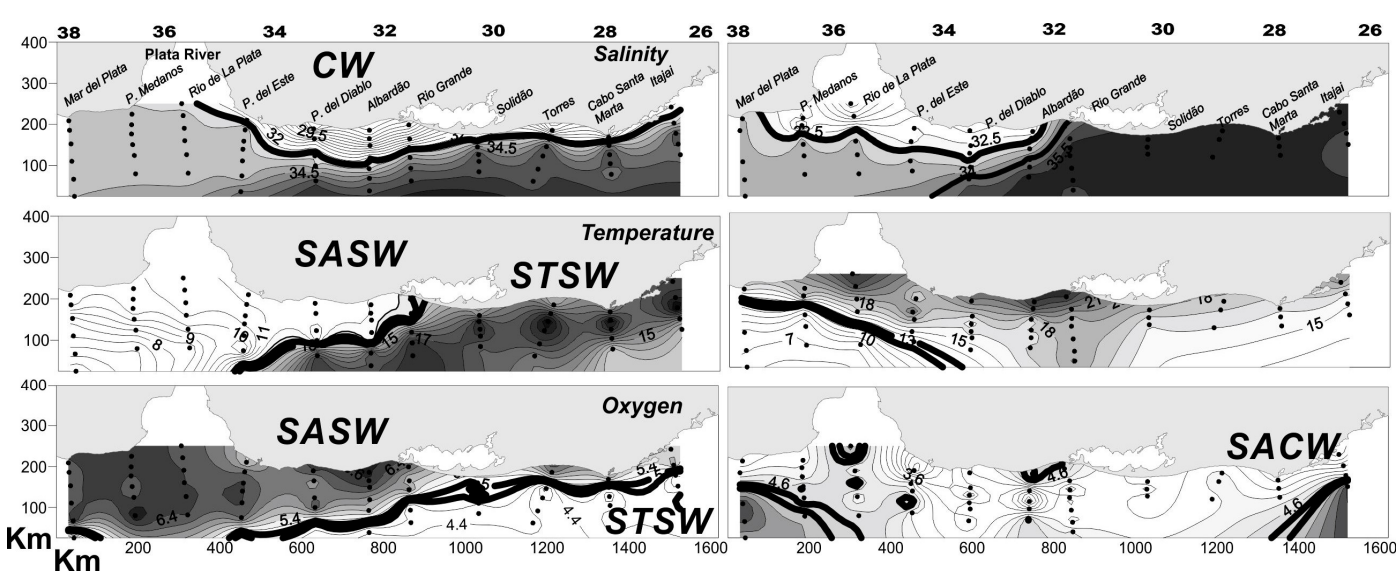

Winter

\section{Summer}
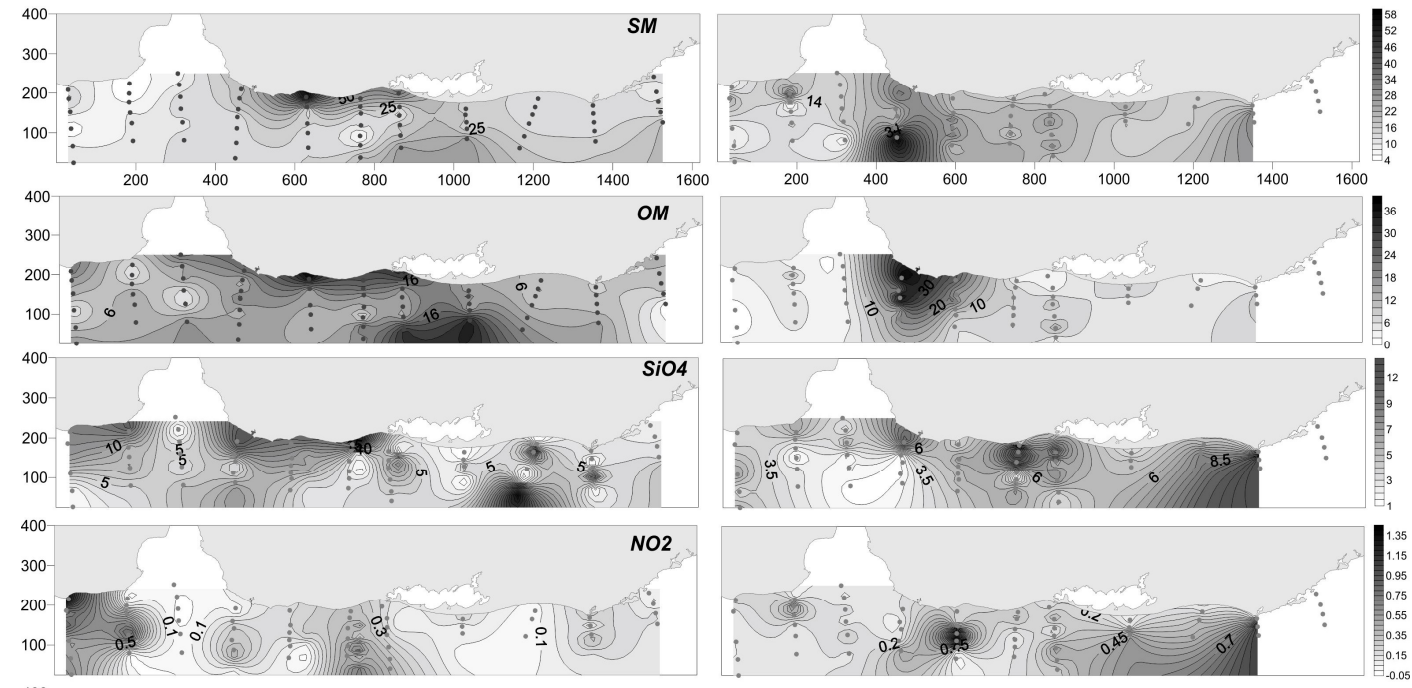

714
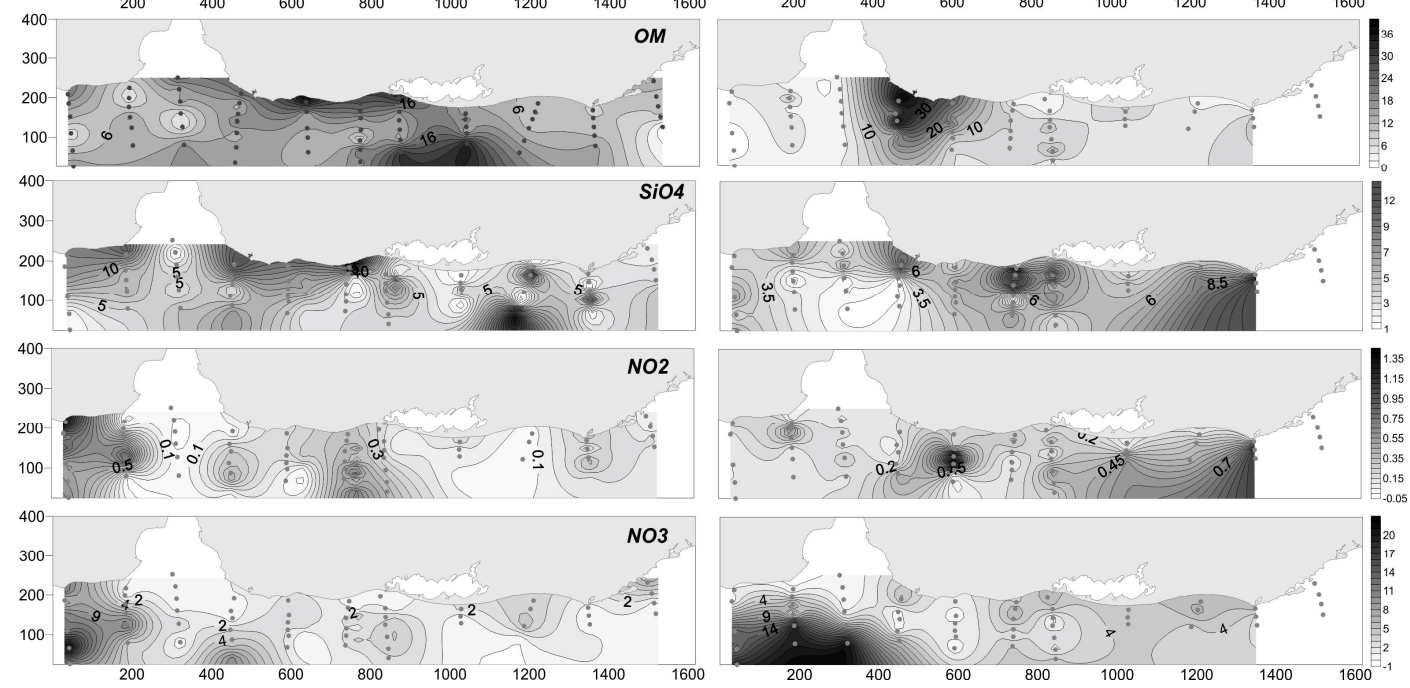
Winter

Summer

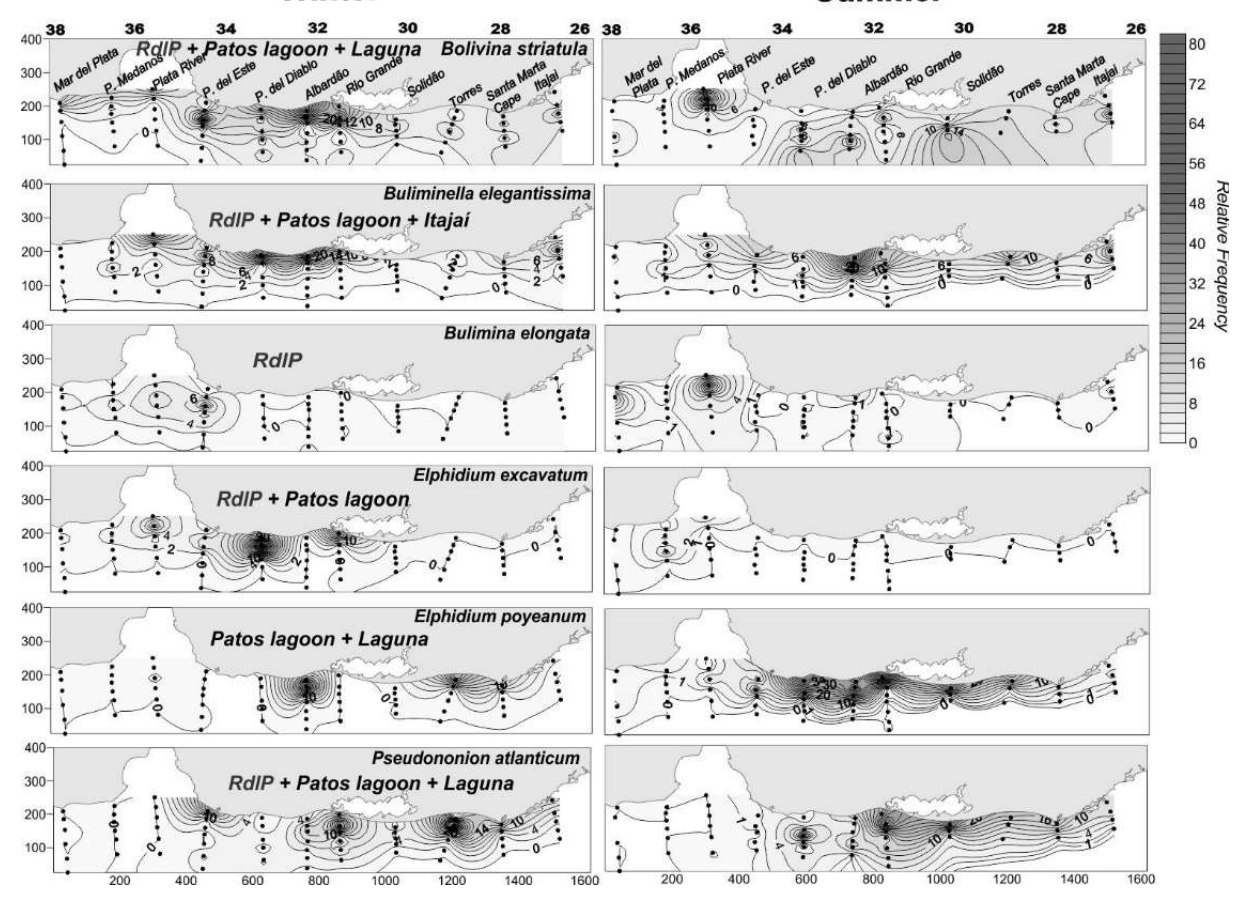

Winter

Summer

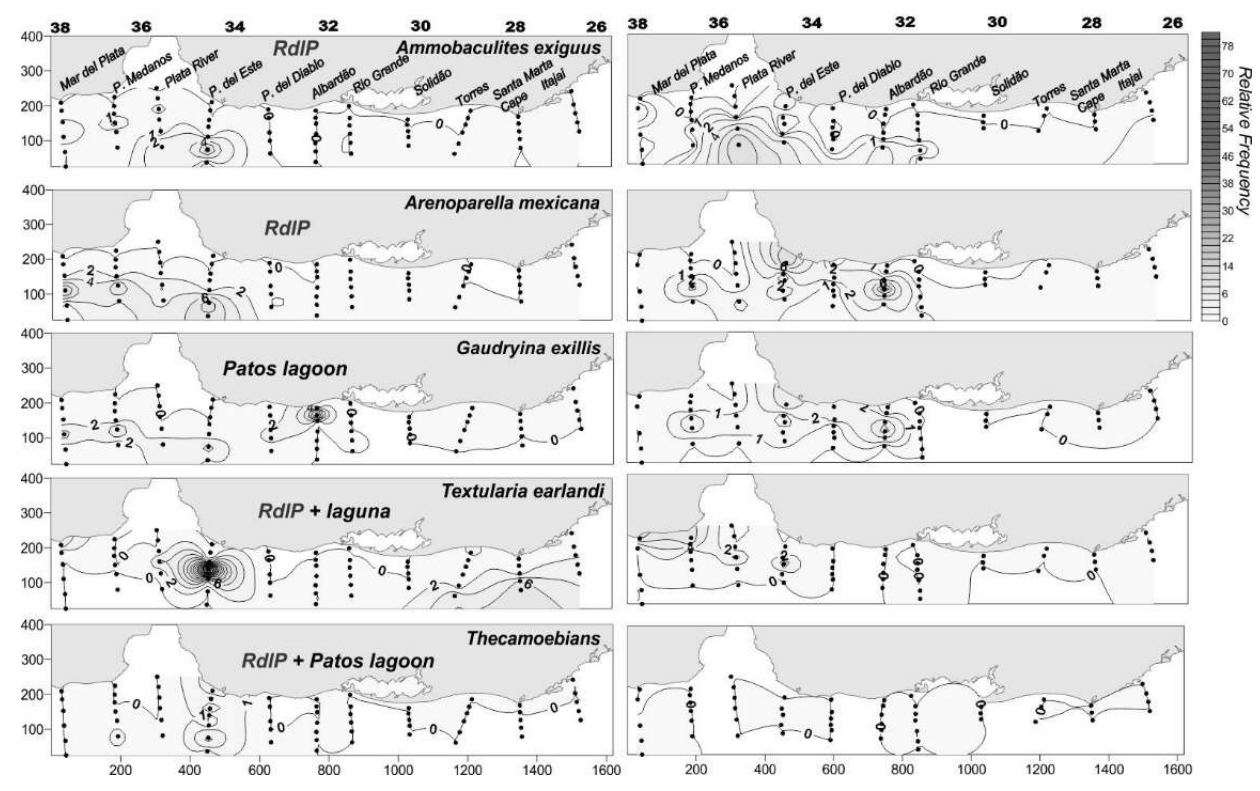

716 


\section{Grain Size}
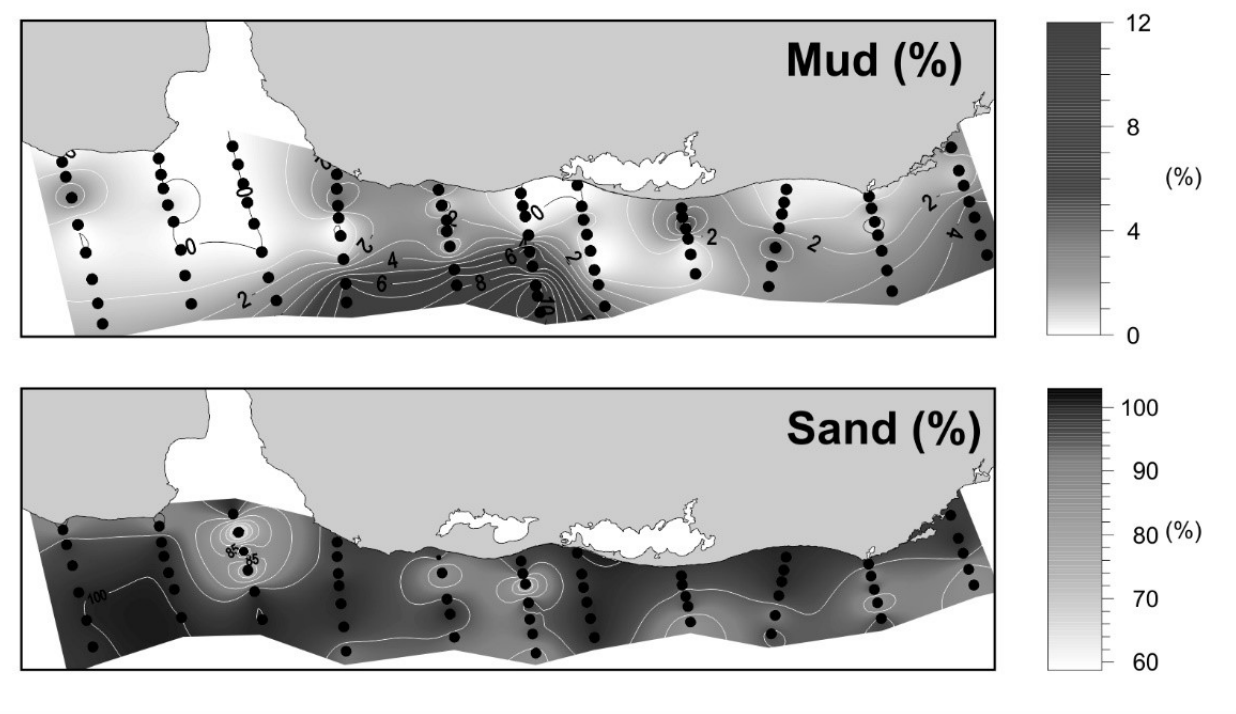

717
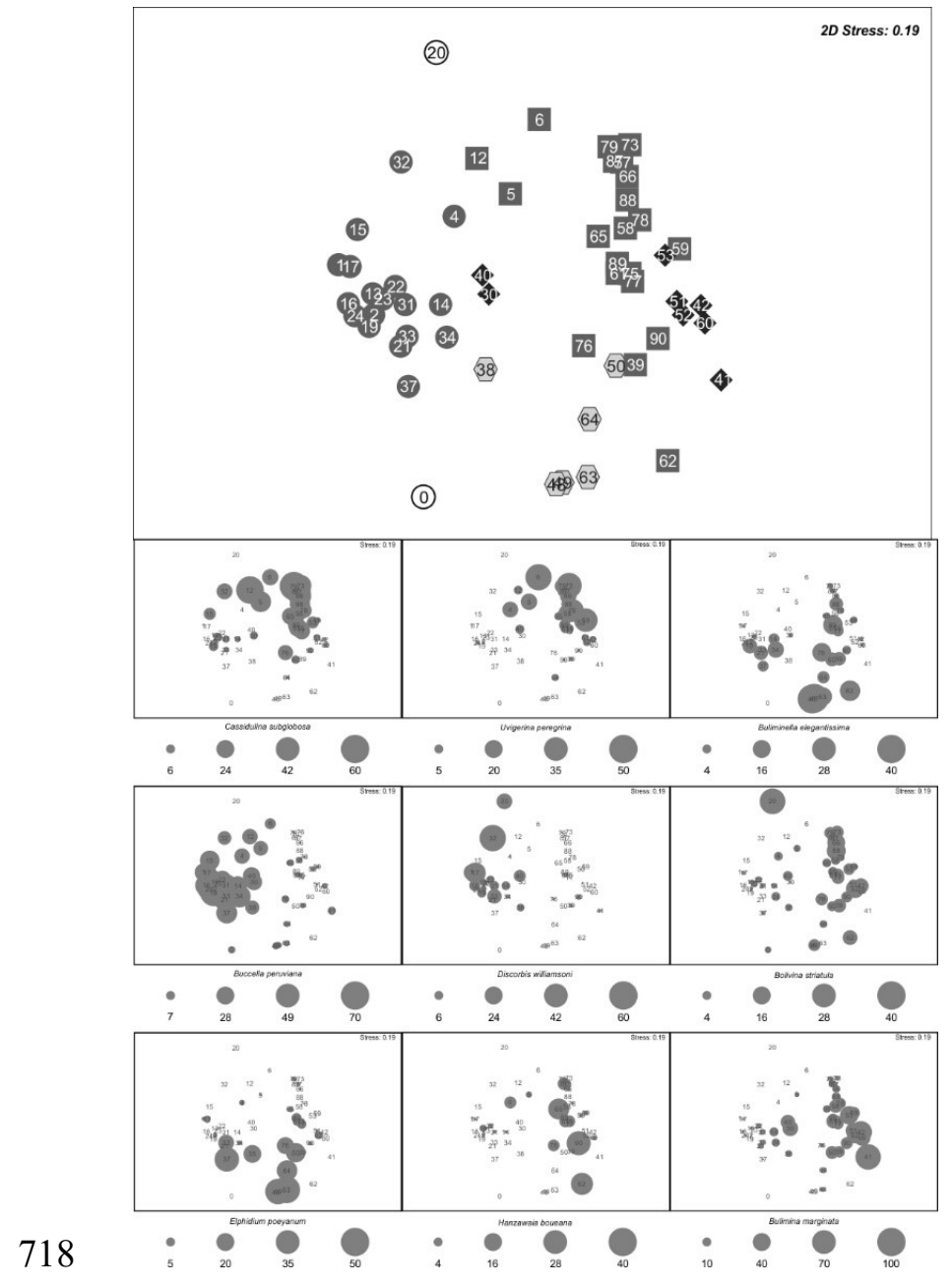


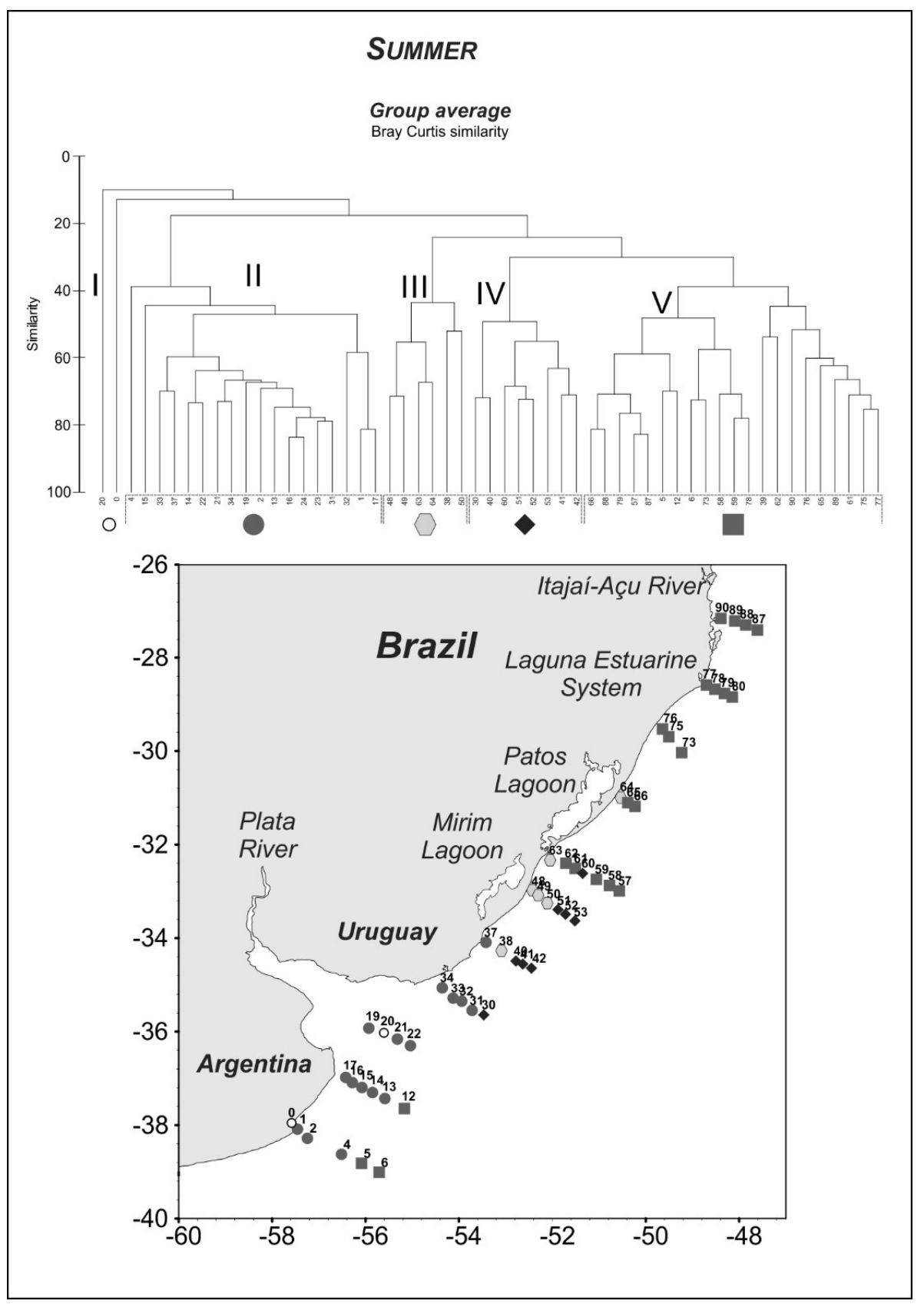

719 

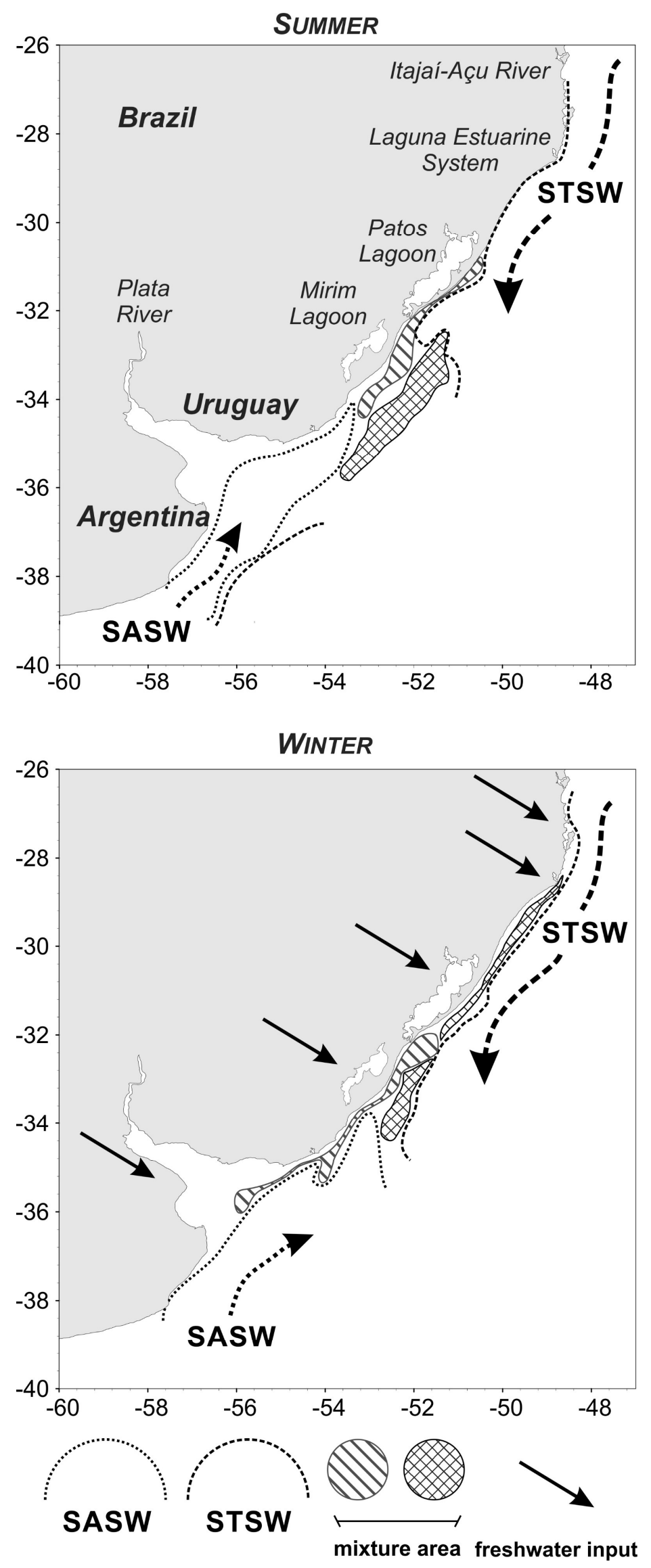


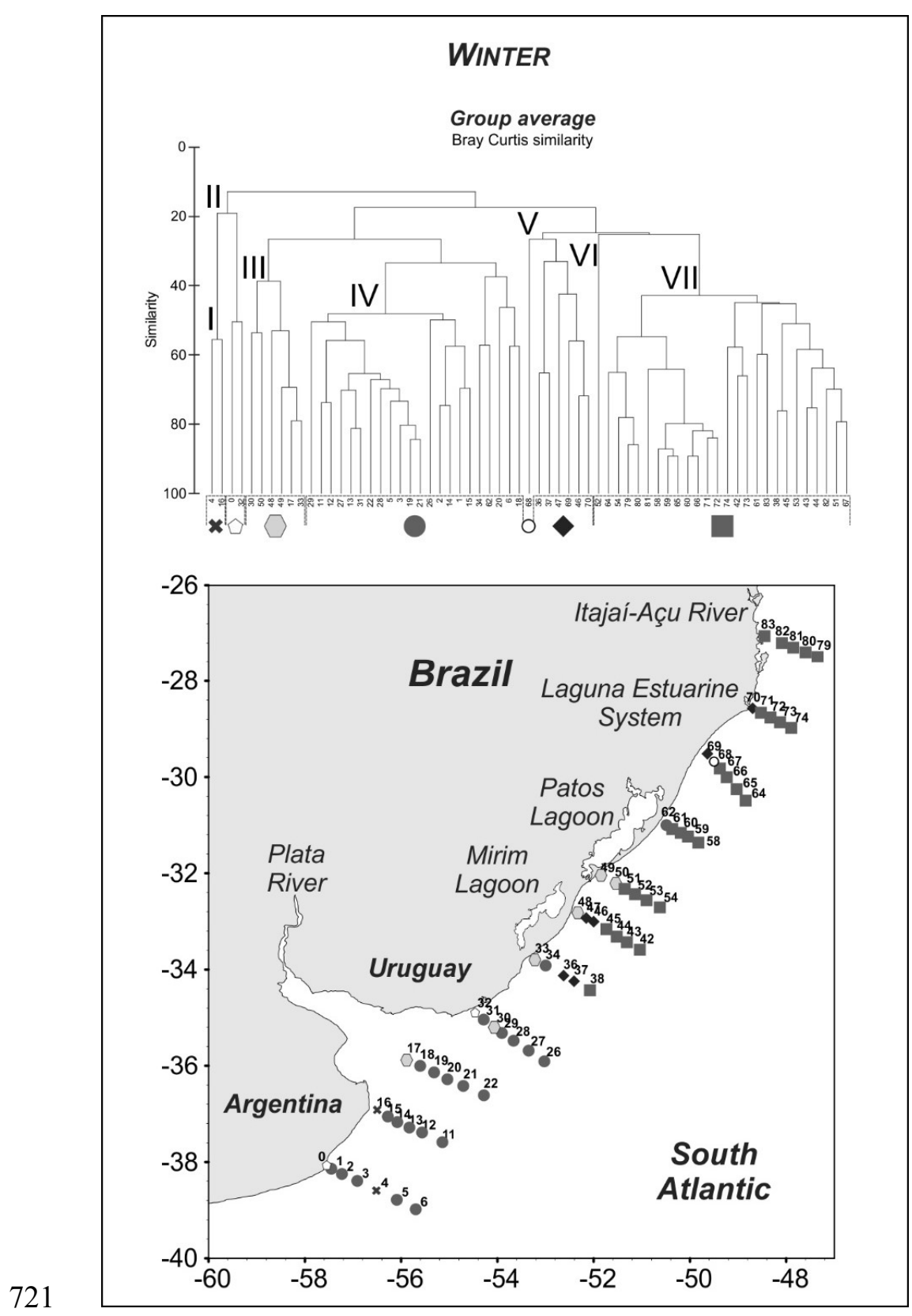




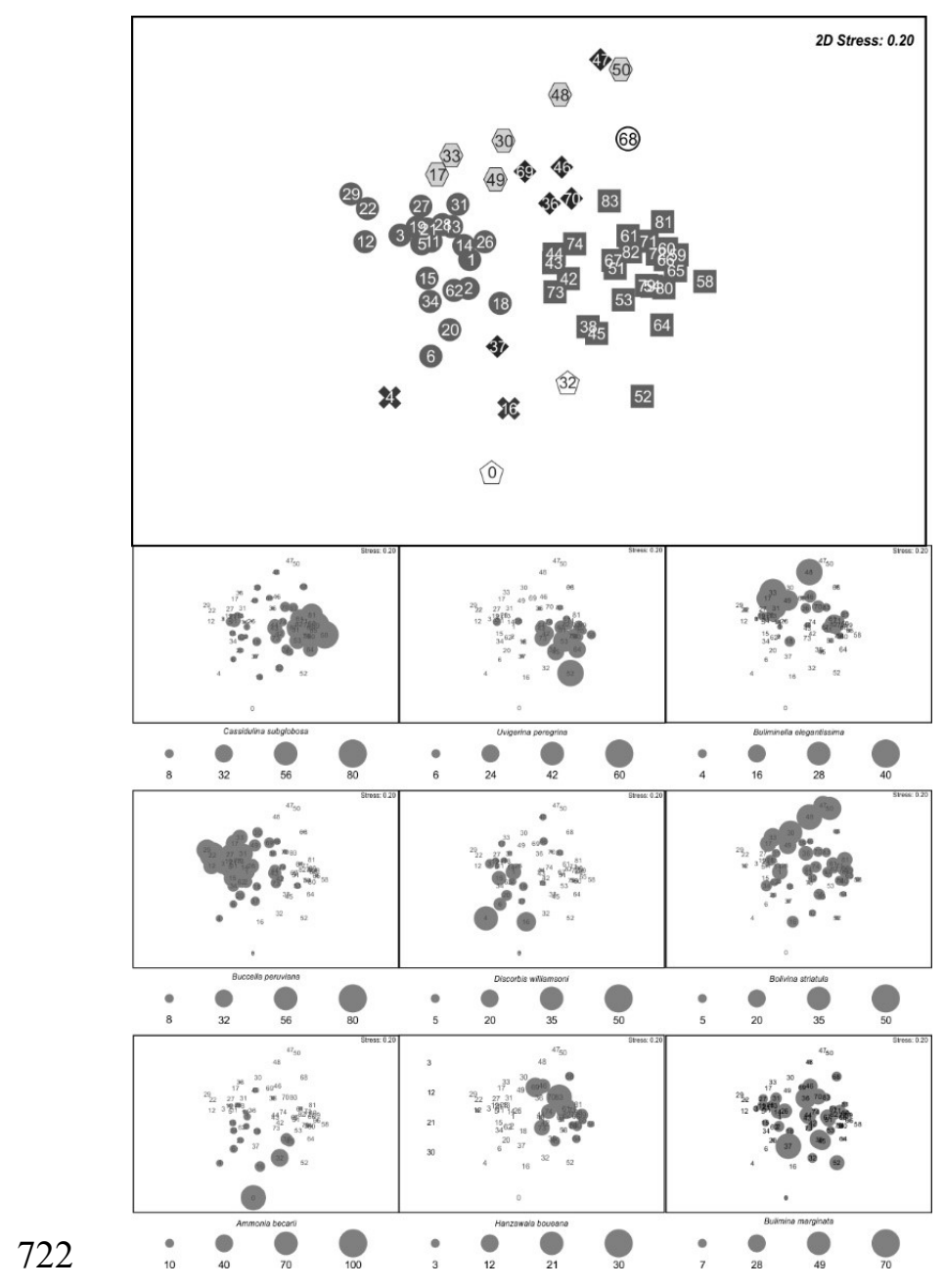



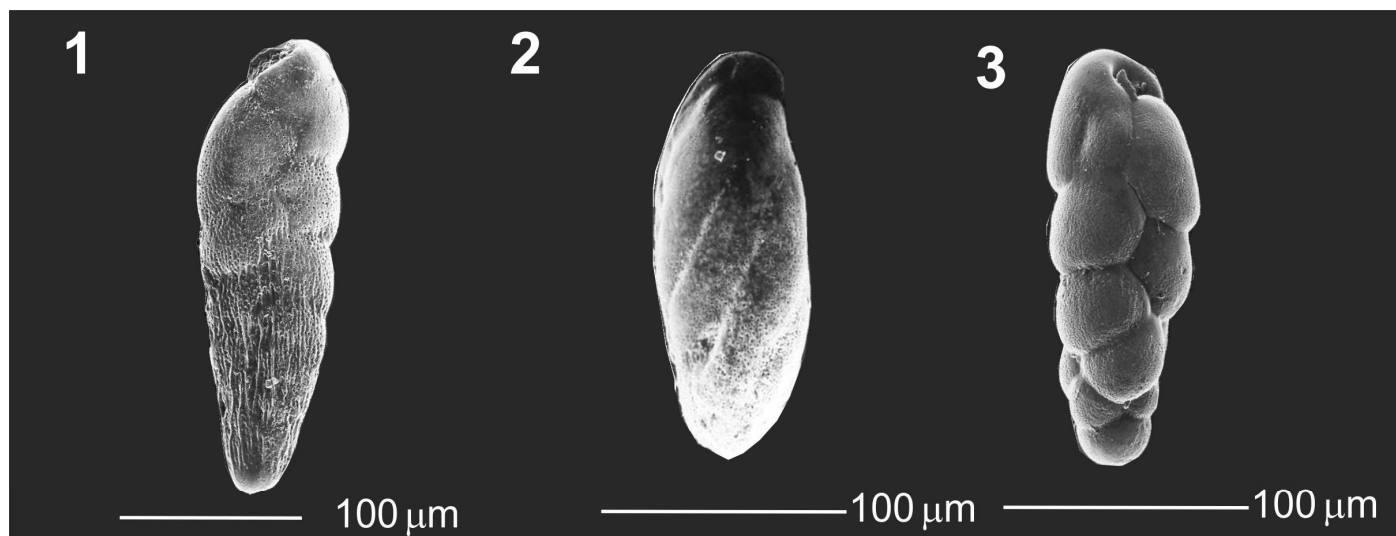

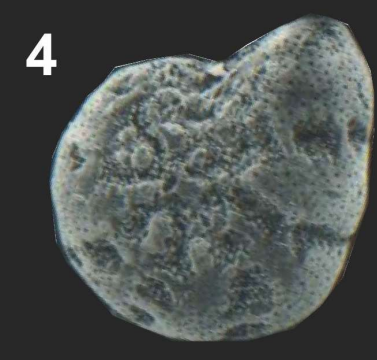

5
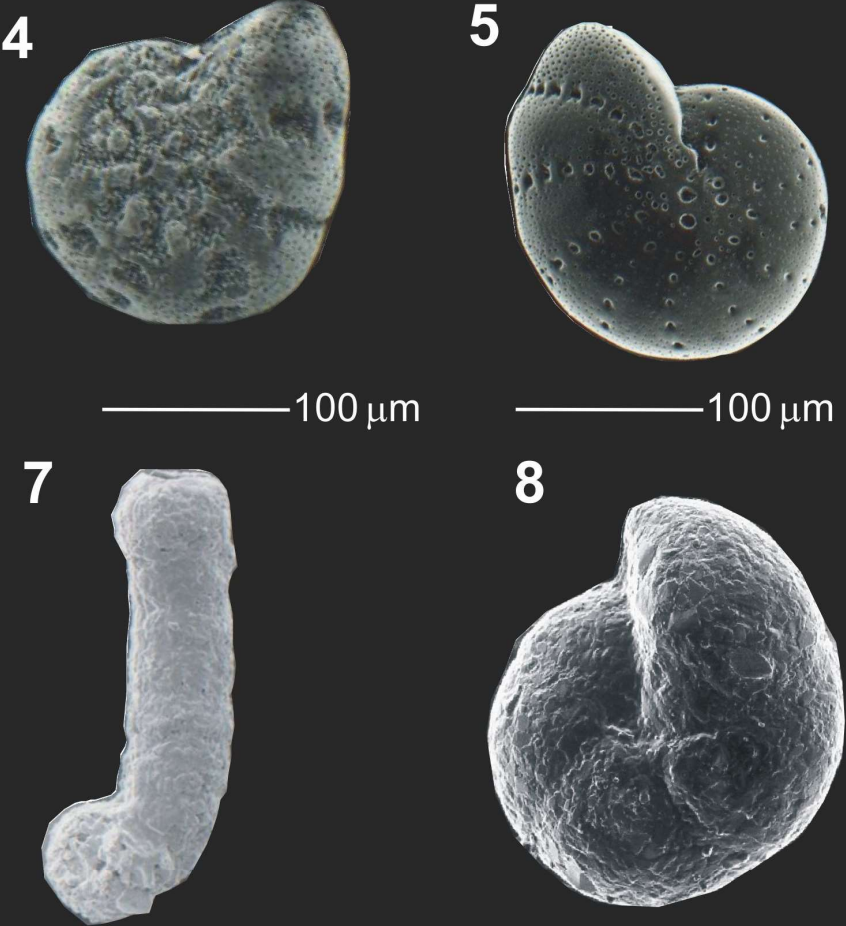

- $10 \mu \mathrm{m}$

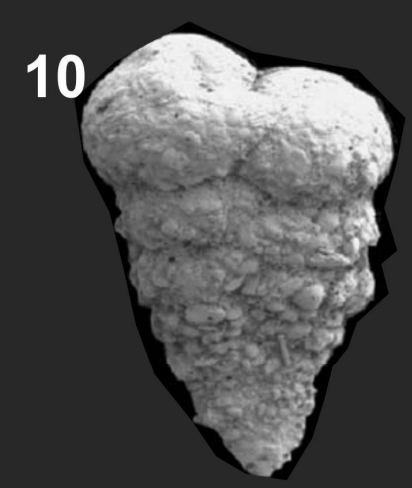

$-10 \mu \mathrm{m}$
$-100 \mu \mathrm{m}$
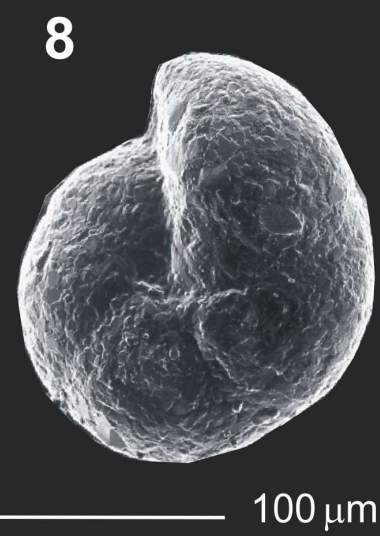

11

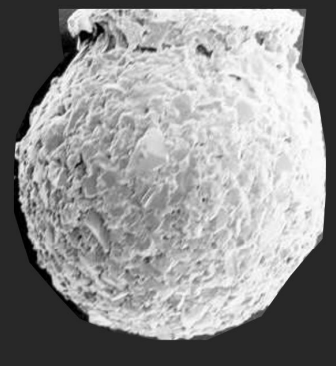

$100 \mu \mathrm{m}$

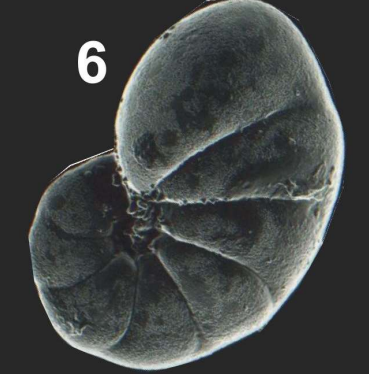

$100 \mu \mathrm{m}$
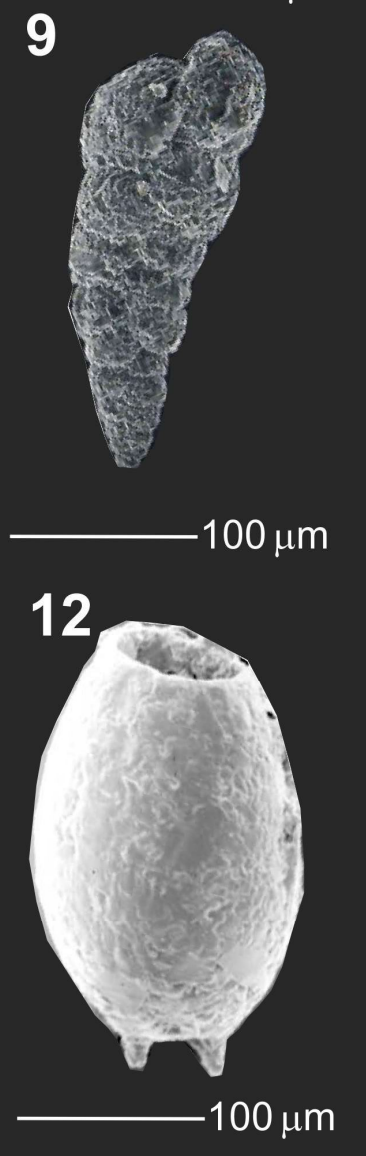